MARINADE Vol. 03(01): $01-10$ (April 2020)

e-ISSN : 2654-4415

online : http://ojs.umrah.ac.id/index.php/marinade

\title{
PENGARUH METODE PENGERINGAN TERHADAP KARAKTERISTIK FISIKOKIMIA IKAN PARI (Dasyatis sp.) KERING
}

\author{
Effect of Drying Methods on Physicochemical Characteristics of Stingray (Dasyatis sp.) \\ Dried
}

\author{
Faisal Susandi ${ }^{1}$, R. Marwita Sari Putri ${ }^{1)}$, Jumsurizal'1) \\ 1) Jurusan Teknologi Hasil Perikanan, Fakultas IImu Kelautan dan Perikanan \\ Universitas Maritim Raja Ali Haji
}

Korespondensi: wita@umrah.ac.id

Diterima : 16 Februari 2020; Disetujui : 28 Maret 2020

\begin{abstract}
Drying is a preservation method by removing or removing air from a material using heat energy. The purpose of this study was to study the interactions and changes in physicochemical characteristics with different drying methods. This study uses a Completely Randomized Design (CRD) with three drying treatmet namely microwave, oven and sunlight. The parameters collected were wet content, ash content, protein content, fat content, salt content, amino acids, TPC (Total Plate Count) and hedonic tests (taste, flavour, color and texture). The results showed a method that was significantly different from wet content, but did not significantly affect ash content, protein content and fat content. While the real storage time for wet content, ash content, protein content, fat content, TPC value and hedonic value. The best combination is oven drying at a temperature of $100^{\circ}-130^{\circ} \mathrm{C}$ for 5 hours with air content of $14.81 \%$, ash content of $2.31 \%$, protein content of $41.87 \%$, fat content of $3.07 \%$, salt content of $4.01 \%$, taste value 9.4 , flavour 9.26 , color 8.86 , texture 8.73 and value of TPC (Total Plate Count) $2.5 \times 10^{2}$.
\end{abstract}

Keyword : stingray dried, physicochemical characteristics, drying, storage.

\begin{abstract}
ABSTRAK
Pengeringan merupakan metode pengawetan dengan mengeluarkan atau menghilangkan air dari suatu bahan menggunakan energi panas. Tujuan penelitian ini adalah untuk mengetahui pengaruh dan perubahan karakteristik fisikokimia dengan metode pengeringan berbeda. Penelitian ini menggunakan Rancangan Acak Lengkap (RAL) dengan tiga perlakuan pengeringan yaitu microwave, oven dan sinar matahari. Parameter yang diamati adalah kadar air, kadar abu, kadar protein, kadar lemak, kandungan garam, asam amino, TPC (Total Plate Count) dan uji hedonik (rasa, aroma, warna serta tekstur). Hasil penelitian menunjukan metode pengeringan berbeda berpengaruh nyata terhadap kadar air, namun tidak berpengaruh nyata terhadap kadar abu, kadar protein dan kadar lemak. Sedangkan lama penyimpanan berpengaruh nyata terhadap kadar air, kadar abu, kadar protein, kadar lemak, nilai TPC dan nilai hedonik. Kombinasi perlakuan terbaik yaitu oven pada suhu $100^{\circ}-130^{\circ} \mathrm{C}$ selama 5 jam dengan kadar air $14,81 \%$, kadar abu $2,31 \%$, kadar protein $41,87 \%$, kadar lemak 3,07\%, kadar garam 4,01\%, nilai rasa 9,4 , aroma 9,26, warna 8,86, tekstur 8,73 dan nilai TPC (Total Plate Count) 2,5 × 10².
\end{abstract}

Kata kunci : ikan pari kering, karakteristik fisikokimia, pengeringan, penyimpanan. 


\section{PENDAHULUAN}

Ikan pari merupakan salah satu produk perikanan yang dikenal cukup luas oleh masyarakat di Indonesia. Saat ini ikan pari telah dimanfaatkan secara optimal menjadi berbagai produk seperti ikan asin, ikan asap dan kerupuk kulit ikan pari. Ikan pari memiliki tingkat protein yang tinggi pada dagingnya sehingga penanganan yang kurang baik dapat menyebabkan denaturasi protein (Wicaksono et al. 2014). Protein dalam daging menjadi indikator pembusukan oleh aktifitas mikroba selama penyimpanan. Selama penyimpanan tersebut aktifitas mikroba mengakibatkan terjadinya dekomposisi senyawa kimia dalam daging dan protein akan dipecah menjadi senyawa yang lebih sederhana sehingga menghasilkan bau busuk. Proses pembusukan ini akan diikuti oleh peningkatan kadar air dan perkembangan mikroba yang berdampak pada aspek fisikokimia produk tersebut (Sukmawati 2018).

Minimnya pengetahuan konsumen mengenai karakteristik fisikokimia selama penyimpanan menjadi permasalahan konsumen dalam mengkonsumsi produk perikanan. Hal ini sebaiknya diperhatikan, karena produk perikanan diketahui mudah rusak dan terkontaminasi sehingga kualitas fisikokimianya mengalami perubahan saat disimpan pada suhu ruang. Agar kualitas fisikokimia terjaga dan produk perikanan bertahan lebih lama maka dilakukan pengolahan terlebih dahulu, seperti pengeringan. Pengeringan merupakan suatu metode menghilangkan kadar air dari suatu bahan dengan cara penguapan dengan energi panas. Secara umum keuntungan pengawetan ini adalah bahan menjadi awet dan volume bahan menjadi kecil. Tujuan pengeringan adalah mengurangi kadar air bahan sampai batas dimana mikroorganisme dan kegiatan enzim yang menyebabkan pembusukan akan terhenti, dengan demikian bahan yang dikeringkan memiliki umur simpan yang panjang (Riansyah et al. 2013).

Penyimpanan merupakan aspek penting setelah proses penangkapan dan pengolahan ikan. Penyimpanan bertujuan untuk mencegah atau mengurangi kerusakan, dan menjaga produk agar bertahan lebih lama (Olii 2018). Penyimpanan terbagi atas beberapa jenis, salah satunya penyimpanan suhu ruang. Penyimpanan ini banyak dilakukan oleh produsen atau konsumen, sehingga sangat diperlukan ketahanan produk agar kerusakan karakter fisikokimia didalam produk terhambat. Kerusakan ini berdampak pada penurunan kualitas mutu dan penerimaan kosumen (acceptability) terutama pada produk ikan pari kering, sehingga sangat diperlukan informasi mengenai perubahan karakteristik fisikokimia selama penyimpanan suhu ruang.

\section{BAHAN DAN METODE}

\section{Bahan dan Alat}

Bahan utama yang digunakan terdiri dari air bersih, es serbuk, aquades, nutrient agar (NA), , dan ikan pari segar (Dasyatis sp.) yang diperoleh dari Pelabuhan Perikanan Kampung Baru Kijang.

Peralatan yang digunakan adalah autoclave, microwave, oven, homogenizer, gelas kimia, labu ukur, pipet tetes, magnetic stire, kertas saring, kapas, plastik wrapping, timbangan analitik, alumunium foil, styrofoam, baskom, talenan, rak penirisan dan pisau daging.

\section{Metode Penelitian Tahap Persiapan Bahan Baku}

Ikan pari segar yang disimpan dalam styrofoam berisi es kemudian dilakukan 
penyiangan, pencucian, dan penirisan. Setelah penirisan selesai selanjutnya dilakukan pengkarakteristikan bahan baku dan persiapan sampel uji.

\section{Tahap Pengeringan}

Pengeringan dilakukan dengan tiga perlakuan yaitu pengeringan microwave, pengeringan oven dan pengeringan sinar matahari. Pada tahap ini proses pengeringan microwave dilakukan pada suhu $150^{\circ} \mathrm{C}$ selama 40 menit (Widyasanti et al. 2019), pengeringan oven dilakukan pada suhu $100-130^{\circ} \mathrm{C}$ selama 5 jam (Riansyah, et al. 2013) dan pengeringan sinar matahari dilakukan seperti penjemuran biasa pada suhu $\pm 40^{\circ} \mathrm{C}$ selama 4-5 hari dengan intensitas penjemuran 8 jam/hari (Suwarno dan Prasetyo 2008).

\section{Tahap Pengujian Mutu}

Ikan pari segar yang telah dikarakterisasi kemudian dilakukan pengujian asam amino (AOAC 2005). Ikan pari yang telah dikeringkan dengan perlakuan berbeda selanjutnya dilakukan pengujian kadar air, kadar abu, kadar protein, kadar lemak (AOAC 2005), uji garam (Salosa 2013), uji TPC (Total Plate Count), uji hedonik (Lim 2011) pada 30 panelis.

\section{Analisis Data}

Data yang telah diperoleh diolah menggunakan software Microsoft Excel, Rancangan Acak Lengkap dan Kruskalwallis menggunakan software SPSS 21. Kemudian data ikan pari dengan perlakuan berbeda dibandingkan satu sama lain dan data ikan pari yang disimpan kemudian dilakukan analisa keterkaitan antara nilai TPC dan hedoniknya.

\section{HASIL DAN PEMBAHASAN}

\section{Analisis Proksimat}

Analisis proksimat merupakan analisis mengenai komposisi kimia suatu bahan yang sangat penting dilakukan untuk memperoleh informasi mengenai kandungan gizi yang terdapat di dalam bahan pangan. Analisis proksimat dalam penelitian ini meliputi kadar air, kadar abu, protein, lemak. Hasil analisis proksimat ikan pari kering dapat dilihat pada Tabel 1.

Tabel 1. Hasil analisis proksimat ikan pari kering dengan metode pengeringan berbeda

\begin{tabular}{lccc}
\hline Analisis & \multicolumn{3}{c}{ Hasil (\%) } \\
\cline { 2 - 4 } Proksimat & Microwave & Oven & $\begin{array}{c}\text { Sinar } \\
\text { Matahari }\end{array}$ \\
\hline Air & 16,09 & 14,81 & 17,97 \\
Abu & 2,34 & 2,31 & 2,10 \\
Protein & 42,09 & 41,87 & 42,11 \\
Lemak & 3,18 & 3,07 & 3,55 \\
\hline
\end{tabular}

\section{Kadar Air}

Nilai kadar air ikan pari yang dikeringkan dengan oven pada suhu 100$130^{\circ} \mathrm{C}$ selama 5 jam merupakan nilai terendah sebesar $14,81 \%$ sedangkan nilai kadar air tertinggi diperoleh pada pengeringan sinar matahari pada suhu \pm $40^{\circ} \mathrm{C}$ selama 8 jam per hari sebesar $17,97 \%$. Rendahnya nilai kadar air pengeringan oven diakibatkan oleh suhu tinggi dan terkontrol sehingga kandungan air terdegradasi. Menurut Parfiyanti et al. (2016), suhu bahan selama proses pengeringan tidak hanya dipengaruhi oleh kadar air awal dan akhir namun juga dipengaruhi oleh suhu pengering. Nilai kadar air tertinggi pada pengeringan sinar matahari disebabkan oleh tidak terkontrolnya suhu pengering dan panas yang dihasilkan tidak dapat diatur sehingga kadar air tidak menghilang secara banyak bebeda dengan 
pengeringan oven. Menuurut Ardianto et al. (2017), berhasilnya proses pengeringan ditunjukan dengan berkurangnya kadar air bahan, berubahnya berat bahan dan tekstur.

Hasil analisis keragaman menunjukan bahwa perlakuan pengeringan berbeda berpengaruh nyata terhadap kadar air ikan pari kering. Uji DMRT pengaruh metode pengeringan terhadap kadar air ikan pari kering menunjukan diantara keseluruhan perlakuan berbeda nyata dan keseluruhan nilai kadar air pada metode pengeringan sudah memenuhi standar mutu SNI 012721-2009. Menurut penelitian Ummah et al. (2016), semakin tinggi suhu dan laju aliran udara pengeringan bawang merah, maka semakin banyak pula kadar air yang terlepas dan menghilang dari bawang tersebut. Semakin cepatnya aliran udara pengering maka semakin cepat masa uap air dipindahkan ke atmosfir. Berkurangnya kadar air mengakibatkan tingginya kadar abu, protein dan lemak (Ahmed et al. 2010).

\section{Kadar Abu}

Nilai kadar abu tertinggi diperoleh dari pengeringan microwave pada suhu $150^{\circ} \mathrm{C}$ selama 40 menit sebesar 2,33\%. Sedangkan nilai kadar abu terendah diperolah dari pengeringan sinar matahari pada suhu $\pm 40^{\circ} \mathrm{C}$ selama 8 jam $/$ hari. Tingginya nilai kadar abu pada pengeringan microwave disebabkan oleh rendahnya kadar air yang dihasilkan pengeringan ini dan terkontrolnya suhu yang digunakan. Rendahnya nilai kadar abu sinar matahari disebabkan oleh suhu pengeringan yang tidak dapat dikontrol menjadikan bahan masih mengandung air dan menurunkan nilai kadar abu. Menurut Erfiza et al. (2018), peningkatan kadar abu terjadi karena adanya keterkaitan antara air dan struktur daging, yang apabila dipanaskan akan meningkatkan kadar abu.

Berdasarkan analisis keragaman menunjukan bahwa perlakuan metode pengeringan berbeda pada taraf $5 \%$ tidak berpengaruh nyata terhadap kadar abu ikan pari kering. Uji DMRT (Duncan's Multipe Range Test) menunjukan keseluruhan pengeringan tidak berpengaruh pada kadar abu ikan pari dan nilai kadar abu yang dihasilkan melampaui standar mutu SNI 01-2721-2009 yakni maksimal 0,3\%. Lebihnya hasil ini dipengaruhi oleh ekosistem air laut yang mengandung garam tinggi juga mineral lainnya. Menurut Kinakesti et al. (2017), ikan pari merupakan ikan pemakan di dasar laut (bottom feeder), sehingga sangat dimungkinkan kandungan mineral laut terkonsumsi oleh ikan dan diserap kedalam dagingnya.

\section{Kadar Protein}

Kadar protein terendah diperoleh perlakuan pada pengeringan oven pada suhu $100-130^{\circ} \mathrm{C}$ selama 5 jam sebesar $41,87 \%$ dan nilai kadar abu tertinggi diperoleh dari perlakuan pengeringan sinar matahari pada suhu $\pm 40^{\circ} \mathrm{C}$ selama 8 jam/hari sebesar $42,11 \%$. Jumlah kadar protein yang tidak berbeda jauh ini berkaitan dengan kadar air dan kadar abu. Hasil tersebut sesuai dengan hasil dari penelitian Syarifah et al. (2017) yang menyatakan bahwa pemanasan menyebabkan protein terkoagulasi dan terdenaturasi, sehingga protein menjadi tidak terlarut. Selain itu Menurut Picauly et al. (2015), energi panas juga memberi dampak terhadap kualitas protein didalam daging ikan, termasuk asam amino sehingga protein harus dihidrolisis sehingga menghasilkan asam amino bebas.

Berdasarkan analisis keragaman DMRT (Duncan's Multiple Range Test) 
pada taraf 5\% menunjukan bahwa perlakuan metode pengeringan berbeda tidak berpengaruh nyata terhadap kadar protein ikan pari kering, hal ini terjadi diduga adanya protein fibril dalam jumlah besar, sehingga pada saat pemanasan berlangsung proses kerusakan protein yang terjadi hanya sedikit. Hal ini didukung Telaumbanua et al (2012), dimana protein yang terkandung didalam ikan pari hanya berkurang sedikit, meski telah dilakukan pengolahan dan ekstraksi. Dari penelitian yang dilakukam Telaumbanua et al. (2012), diketahui protein yang terkandung dalam ikan pari sebesar $45,68 \%$ dan hanya berbeda 3-4\% dengan kadar protein pada penelitian ini.

\section{Kadar Lemak}

Nilai kadar lemak terendah diperoleh pada perlakuan pengeringan oven pada suhu $100-130^{\circ} \mathrm{C}$ selama 5 jam sebesar $3,07 \%$ dan nilai kadar lemak tertinggi diperoleh dari perlakuan pengeringan sinar matahari pada suhu $\pm 40^{\circ} \mathrm{C}$ selama 8 jam/hari sebesar $3,55 \%$. Perbedaan tinggi rendahnya nilai kadar lemak ini diakibatkan oleh terkontrolnya suhu dan waktu pengeringan. Menurut Huriawati et al. (2016), perlakuan suhu dan waktu pengeringan pada bahan sehingga dapat menyebabkan kerusakan lemak dan jumlahnya yang menurun. Nilai kadar lemak pada penelitian ini berada diatas kadar lemak yang diperoleh dari penelitian Swastawati et al. (2017) yakni sebesar $3,25 \%$, artinya meski dilakukan pengeringan, kadar lemak dalam daging ikan masih terdapat cukup banyak dan hanya berkurang sedkit akibat pengeringan

Berdasarkan analisis keragaman
menunjukan bahwa perlakuan
pengeringan tidak berpengaruh nyata
terhadap kadar lemak ikan pari kering. Uji
DMRT (Duncan's Multiple Range Test)

pada taraf $5 \%$ memperlihatkan keseluruhan perlakuan pengeringan tidak memberikan pengaruh nyata terhadap kadar lemak ikan pari kering. Tidak berpengaruhnya nilai lemak ini dapat disebabkan karena umur panen dan laju metabolisme orgaanisme. Lemak semakin meningkat dengan bertambahnya usia, karena sifat fisologis ikan yang akan menuju fase perkembangbiakan. Hewan akan membutuhkan lebih banyak energi yang dismpan dalam bentuk lemak untuk berkembang biak. Variasi komposisi kimia dapat terjadi antar spesies dan antar individu dalam satu spesies (Faradiana et al. 2018).

\section{Uji Hedonik}

Kriteria yang digunakan dalam uji hedonik ikan pari (Dasyatis sp.) kering disesuaikan dengan skala hedonik Lim (2011) yaitu enak (3), netral (2), dan tidak enak (1). Parameter dalam uji hedonik ini yaitu rasa, aroma, warna, dan tekstur.

\section{Rasa}

Hasil uji hedonik ikan pari (Dasyatis sp.) kering pada paramater rasa dapat dilihat pada Gambar 1.

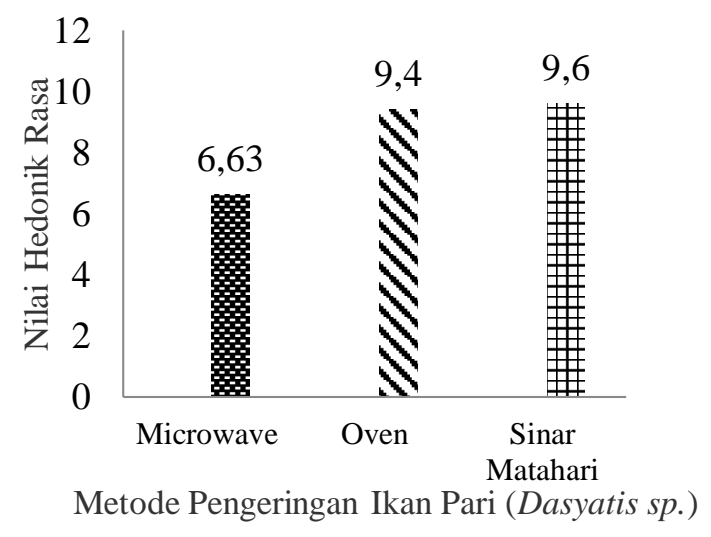

Gambar 1. Nilai hedonik rasa ikan pari kering dengan metode pengeringan berbeda

Berdasarkan uji hedonik rasa ikan pari kering berisar antara 6,63 sampai 9,6. Nilai 
rata-rata tertinggi diperoleh dari perlakuan pengeringan sinar matahari $\left( \pm 40^{\circ} \mathrm{C}\right.$ selama 8 jam/hari) dengan nilai rata-rata 9,6 artinya terdapat $9,6 \%$ panels memberikan nilai 3 (enak) pada uji hedonik tersebut. Tingginya penilaian tersebut diakibatkan oleh pemanasan yang tak terlalu tinggi sehingga rasa asin pada daging tidak terlalu terasa. Sedangkan nilai hedonik terendah diperoleh dari perlakuan pengeringan microwave $\left(150^{\circ} \mathrm{C}\right.$ selama 40 menit) dengan nilai rata-rata 6,63 artinya ada sebanyak $6,63 \%$ panelis memberikan nilai 3 (enak). Rendahnya penilaian ini disebabkan pengaruh suhu yang dipergunakan sehingga membentuk pengkaramelan di permukaan daging dan proses pengorengan juga menyebabkan rasa asin muncul pada daging.

Berdasarkan analisis Kruskall-wallis perlakuan microwave, oven, dan sinar matahari dengan tingkat kepercayaan $95 \%$, tidak berpengaruh nyata terhadap rasa. Penilaian panelis terhadap parameter rasa ikan pari kering diduga karena panelis menyukai rasa yang tidak terlalu asin, warna tidak terlalu mencolok. Perlakuan sinar matahari juga menunjukan kadar garam yang tidak terlalu tinggi maupun terlalu rendah. Rasa yang tercipta pada ikan pari kering dihasilkan dari garam yang terkandung di dalam daging akibat penyimpanan ikan di kapal.

\section{Aroma}

Hasil uji hedonik ikan pari (Dasyatis sp.) kering pada parameter aroma dapat dilihat pada Gambar 2. Berdasarkan uji hedonik mutu nilai hedonik aroma ikan pari kering pada metode pengeringan berbeda berkisar antara 8,80 sampai 9,26. Nilai hedonik mutu tertinggi diperoleh dari pengeringan oven $\left(100^{\circ} \mathrm{C}\right.$ sampai $130^{\circ} \mathrm{C}$ selama 600 menit atau 5 jam) dengan nilai 9,26 (ada sebanyak 9,26\% panelis memberikan nilai 3 (enak) pada uji hedonik tersebut. Tingginya nilai hedonik ini disebabkan oleh suhu yang tinggi, sehingga daging pecah dan aroma dari dalam daging keluar. Sedangkan nilai hedonik terendah diperoleh dari pengeringan microwave $\left(150^{\circ} \mathrm{C}\right.$ selama 30 menit) dengn nilai hedonik 8,8 artinya ada sebanyak $8,8 \%$ panelis memberikan nilai 3 (enak) terhadap ikan pari kering. Penilaian terendah ini disebabkan oleh aroma yang dihasilkan ikan pari sedikit tajam akibat pengeringan pada kulit ikan pari yang tidak merata sehingga tampak seperti lembab. Menurut Situmorang et al. (2008), kulit ikan pari memiliki daya awet dan produktif untuk kerajinan, dan kulit ikan pari merupakan salah satu jenis kulit nonkonvensional yang diketahui kulit ini sangat kuat dibandingkan kulit konvensional seperti kulit sapi, kerbau, kambing, dan lain-lain. Berdasarkan pernyataan tersebut sangat dimungkinkan aroma yang dihasilkan dari kulit tersebut menjadi sebab rendahnya penilaian panelis terhadap hedonik ikan pari kering.

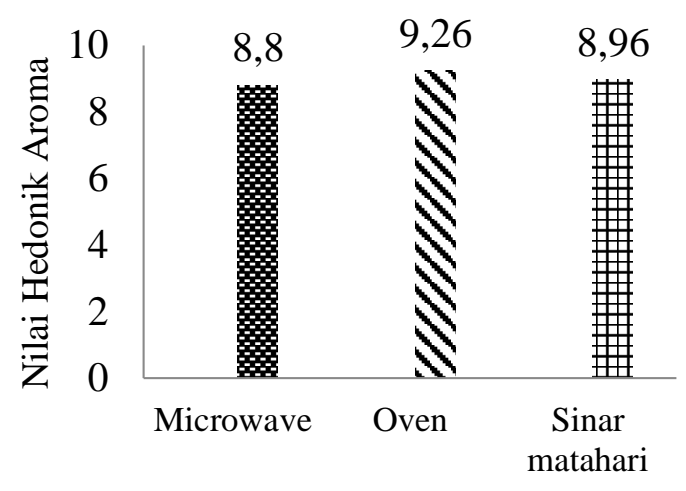

Metode Pengeringan Ikan Pari (Dasyatis sp.)

Gambar 2. Nilai hedonik aroma ikan pari kering dengan metode pengeringan berbeda.

Berdasarkan analisis Kruskall-wallis perlakuan microwave, oven, dan sinar matahari dengan tingkat kepercayaan 
95\% pada taraf $\square=5 \%$ memberikan pengaruh pada aroma ikan pari kering. Pengaruh ini disebakan oleh variasi pengeringan yang digunakan sehingga aroma yang dimunculkan berbeda bahkan aroma khas ini disukai beberapa panelis.

\section{Warna}

Hasil uji hedonik ikan pari (Dasyatis sp.) kering pada parameter warna dapat dilihat pada Gambar 3.

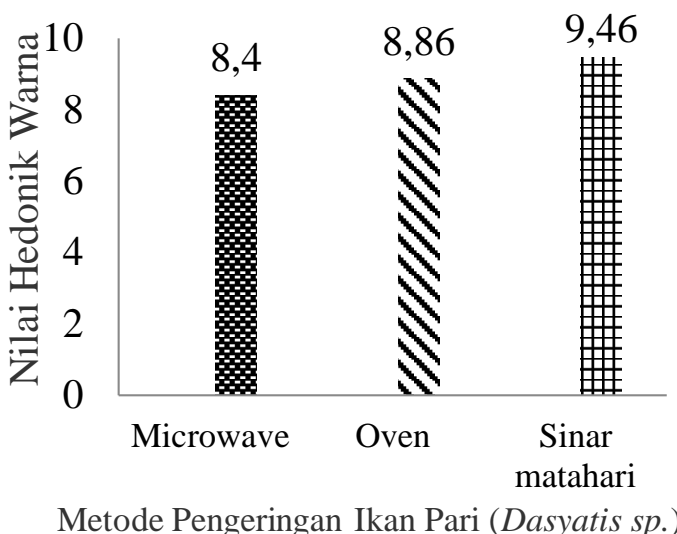

Gambar 3. Nilai hedonik warna ikan pari kering dengan metode pengeringan berbeda

Berdasarkan uji henonik warna pada ikan pari dengan metode pengeringan berbeda nilai berkisar antara 8,40 sampai 9,46 . Pada penelitian ini nilai hedonik tertinggi diperoleh dari pengeringan sinar matahari pada waktu pengeringan selama 8 jam/hari pengeringan dengan nilai 9,46, artinya ada sebanyak $9,46 \%$ panelis memberikan nilai 3 (enak) pada warna ikan pari kering tersebut. Tingginya nilai yang diberikan panelis tidak terlepas dari cara pengeringan dan intensitas cahaya serta interval waktu yang digunakan. Warna yang dihasilkan pada pengeringn ini tidak terlalu tajam atau mencolok, warna kuning muda disekitar permukaan ikan. Sedangkan nilai hedonik terendah diperoleh dari pengeringan microwave $\left(150^{\circ} \mathrm{C}\right.$ selama 40 menit) memperoleh nilai hedonik 8,40 artinya ada sebanyak 8,40\% panelis menyukai ikan pari kering tersebut.
Rendahnya penilaian hedonik ini disebabkan oleh warna yang dihasilkan pucat pada permukaan. Hal ini diduga disebabkan karena penggunaan panas dengan waktu tertentu dapat menyebabkan reaksi pencoklatan pada daging ikan karena pada reaksi antara protein, peptida, dan asam amino dengan hasil dekomposisi lemak (Handayani et al. 2017). Warna merupakan faktor dominan dalam parameter kenampakan yang mempengaruhi skala penerimaan ikan pari kering karena warna dapat memberikan tanda terjadinya perubahan kimia pada suatu produk pangan (Markovic et al. 2014).

Berdasarkan uji Kruskall-wallis dengan tingkat kepercayaan 95\% pada taraf $\square=5 \%$ perlakuan microwave, oven, dan sinar matahari memberikan pengaruh terhadap kesukaan panelis terhadap warna ikan pari kering. Pengaruh ini disebabkanoleh pengeringan yang dilakukan. Menurut Handoyo et al. (2011), pengeringan akan memberikan perubahan warna, tekstur dan aroma bahan pangan.

\section{Tekstur}

Hasil uji hedonik ikan pari (Dasyatis sp.) kering pada parameter tekstur dapat dilihat pada Gambar 4.

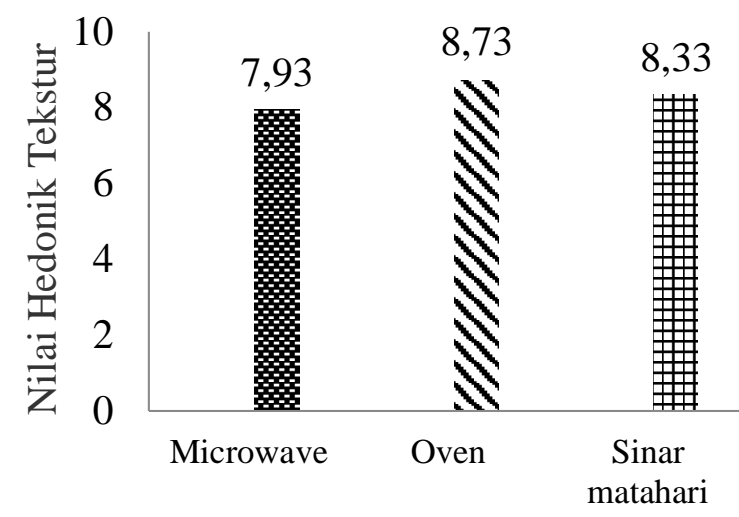

Metode Pengeringan Ikan Pari (Dasyatis sp.)

Gambar 4. Nilai hedonik ikan pari kering dengan metode pengeringan berbeda. 
Berdasarkan nilai uji hedonik tekstur pada pengeringan microwave, oven, dan sinar matahari nilai rata-rata hedonik berkisar antara 7,93 sampai 8,73. Nilai uji hedonik tertinggi diperoleh dari pengeringan oven $\left(100-130^{\circ} \mathrm{C}\right.$ selama 5 jam) dengan nilai 8,73 artinya ada sebanyak $8,73 \%$ panelis menyukai tekstur ikan pari kering. Perolehan nilai yang tinggi ini disebabkan oleh suhu yang dipergunakan saat pengeringan sehingga tekstur menjadi crispy dan saat dilekukan tekstur akan patah. Hal ini sesuai dengan penelitian Tunick et al. (2013), pembentukan tekstur crispy disebabkan oleh pengaruh suhu dan karakter bahan itu sendiri. Adanya penggunaan garam saat penanganan diatas kapal menyebabkan perubahan tekstur setelah pengeringan.

Berdasarkan uji Kruskall-walis dengan tingkat kepercayaan 95\% pada taraf $\square=5 \%$ dapat diketahui bahwa perbedaan perlakuan memberikan pengaruh nyata terhadap nilai hedonik tekstur pada ikan pari. Menurut Veerman et al. (2013), penanganan yang baik dan adanya bahan tambahan juga dapat mempengaruhi tekstur.

\section{KESIMPULAN}

Berdasarkan hasil penelitian, maka dapat disimpulkan metode pengeringan berbeda berpengaruh nyata terhadap kadar air, namun tidak berpengaruh nyata terhadap kadar abu, kadar protein dan kadar lemak. Kombinasi perlakuan terbaik yaitu oven pada suhu $100^{\circ}-130^{\circ} \mathrm{C}$ selama 5 jam dengan kadar air $14,81 \%$, kadar abu $2,31 \%$, kadar protein $41,87 \%$, kadar lemak $3,07 \%$, kadar garam $4,01 \%$, nilai rasa 9,4 , aroma 9,26 , warna 8,86 , tekstur 8,73 dan nilai TPC (Total Plate Count) $2,5 \times 10^{2}$.

\section{DAFTAR PUSTAKA}

Ahmed, E.O., Ali, M.E., Khalid, R.A., Taha, H.M., dan Mahammed, A.A. 2010. Investigating the Quality Change of Raw and Hot Smoked Oreochromis niloticus dan Clarias lazera. Pakistan Jurnal of Nutrition. 9 (5): 481-484

AOAC., 2005. Official Methods of Analysis of the Association of Official Analytical Chemist. Washington.

Ardianto, Jamaluddin, Wijaya, M. 2017. Perubahan Kadar Air Ubi Kayu Selama Pengering Kabinet. Jurnal Pendidikan Teknologi Pertanian. 3: 112-116.

Badan Standarisasi Nasional. 2009. SNI No. 1-2721-2009. Persyaratan Mutu dan Keamanan Pangan Ikan Asin Kering. Jakarta

Erfiza, N.M., Hani, D., Syahrina, U. 2018. Evaluasi Nilai Gizi Masakan Daging Khas Aceh (Sie Reuboh) Berdasarkan Variasi Penambahan Lemak Sapi dan Cuka Aren. Jurnal Teknologi dan Industri Pertanian Indonesia. 10 (1): 2835.

Faradiana, R., Budiharjo, A., Sugiyarto, S. 2018. Keanekaragaman Ikan di Waduk Mulur Sukoharjo, Jawa Tengah, Indonesia. Depik: Jurnal IImu Perairan, Pesisir dan Perikanan. 7 (2): 151-163.

Handayani, B.R., Kusumo, B.D., Werdiningsih, W., Rahayu, T.I., Hariani. 2017. Pro Food (Jurnal Ilmu dan Teknologi Pangan). 3 (1): 194-199.

Handoyo, E.A., Kristanto, P., Alwi, S. 2011. Desain dan Pengujian Sistem Pengering Ikan Bertenega Surya. Jurusan Teknik Mesin. Fakultas Teknologi Industri. Universitas Kristen Petra Wacana. Salatiga

Huriawati, F., Yuhanna, W. L., Mayasari, T. 2016. Pengaruh Metode Pengeringan Terhadap Kualitas Serbuk Seresah (Enhalus acoroides) dari 
Pantai Pacitan. IKIP PGRI Madiun. Bioeksperimen. 2 (1): 35-43.

Kinakesti, S.M., Wahyudewantoro, G. 2017. Kajian Jenis Ikan Pari Dasyatidae di Indonesia. Fauna Indonesia. 16 (2) : 17-25

Lim, J. 2011. Hedonic Scalling: A review and methods and theory. Food Quality and Preference 22. 733-747

Markovic, I., Ilic, J., Markovic, D., Simonovic, V., Kosanic, N. 2014. Color Measurement of Food Products Using CIE L*a*b* and RGB Color Space. Journal of Hygienic Engineering and Design 61: 50-53

Olii, A.H. 2018. Pengemasan, Penyimpanan dan Penggudangan Olahan Perikanan. CV. Artha Samudra. Gorontalo.

Picauly, P., Telahatu, J., Mailoa, M. Pengaruh Penambahan Air Pada Pengolahan Susu Kedelai. Jurnal Agritekno 4 (1): 8-13.

Riansyah, A., Supriadi, A., Nopianti, R. 2013. Pengaruh Perbedaan Suhu dan Waktu Pengeringan Terhadap Karakteristik Ikan Asin Sepat Siam (Trichogaster pectoralis) Dengan Menggunakan Oven. Fishteh Universitas Sriwijaya. Palembang. 2 (1): 53-68.

Salosa, Y.Y. 2013. Uji Kadar Formalin, Kadar Garam, dan Total Bakteri Ikan Asin Tenggiri Asal Kabupaten Sarmi Provinsi Papua. Depik. 2 (1): 10-15

Situmorang, R.Y., Sahubawa, L., Budhiyanti, S.A. 2008. Pengaruh Konsentrasi Mimosa Terhadap Sifat Fisik Kulit Ikan Pari Tersamak. Jurnal Perikanan. 10 (1): 101-109.

Sukmawati. 2018c. Total Microbial Plates on Beef and Beef Offal. Bioscience, 2(1): 22-28.

Suwarno, Prasetyo, T. 2008. Pembuatan Alat Pengering Ikan Teri Hitam Dengan Sistem Udara Hembus Berkapasitas 12
Kg Ikan Basah. Jurnal Orbit. 4 (3): 436441.

Swastawati, F., Cahyono, B., Setiono, I., Kurniasih, R.A. 2017. Penguatan Usaha Pengasapan Ikan "KUB Asap Indah", Desa Wonosari, Kecamatan Bonang, Kabupaten Demak Dengan Teknologi Pengemasan Vakum. Jurnal Info Universitas Diponegoro. 19 (1): 4552

Syarifah, Fatiqin, A., Istiroha. 2017. Sumbangsih Uji Protein Telur Dengan Menggunakan Bawang Putih Pada Mata Pelajaran Biologi Materi Makanan Kelas XI SMA/MA. Bioilmi. 3 (1): 64-70.

Telaumbanua, P.W.H.S., Suparmi., Loekman, S. 2012. Studi Reduksi Urea Pada Daging Ikan Pari (Trygon sephen) Dengan Perendaman Dalam Ekstrak Tauge dan Asam Sitrat. Teknologi Hasil Perikanan dan Kimia Pangan, Fakultas Perikanan dan IImu Kelautan, Universitas Riau. Pekanbaru

Tunick, M.H, Charles, I., Onwulata, Thomas, A.E., Phillips, J.G., Mukhopadhyay, S., Sheen, S., Liu, C.K., Latona, N., Pimentel, M.R., Cooke, P.H. 2013. Critical Evaluation of Crispy and Chrunh Textures: A Review. International Journal of Food Properties. 16 (5): 949-963

Ummah, N., Purwanto, Y.A., Suryani, A. 2016. Penentuan Konstanta Laju Pengeringan Bawang Merah (Allium ascalonium L.) Iris Menggunakan Tunnel Dehydrator. Journal of Agrobased Industry. 33 (2): 49-56.

Veerman, M., Setiyono, Rusman. 2013.

Pengaruh Metode Pengeringan dan Konsentrasi Bumbu Serta Lama Perendaman Dalam Larutan Bumbu Terhadap Kualitas Fisik dan Sensori Dendeng Babi. Buletin Peternakan. 37 (1): 34-40.

Wicaksono, A.T.S., Swastiawati, F., Anggo, A.D. 2014. Kualitas Ikan Pari 
(Dasyatis sp) Asap yang Diolah Dengaan Ketinggian Tungku dan Suhu Yang Berbeda. Jurnal Pengolahan dan Bioteknologi Hasil Perikanan. 3 (1): 147-156.

Widyasanti, A., Silvianur, Zain, S. 2019.

Pengaruh Perlakuan Blanching dan
Level Daya Pengeringan Microwave Terhadap Karakteristik Tepung Kacang Bogor (Vigna subterranea (L.) Verdcourt). Jurnal Teknologi Pertanian Andalas. 23 (1): 2579-4019 